Journal of Qualitative Criminal Justice \& Criminology • 2020 | Volume 9, Issue 1

\title{
"I've Never Been Straight Up Robbed Like That": \\ Resident Perceptions and Experiences of Inner-City Police Raids
}

Marta-Marika Urbanik ${ }^{1}$, Carolyn Greene ${ }^{2}$

${ }^{1}$ University of Alberta, ${ }^{2}$ Athabasca University

Published on: Nov 17, 2020

DOI: $10.21428 / 88 \mathrm{de} 04 \mathrm{a} 1.6 \mathrm{f} 2 \mathrm{a} 66 \mathrm{fb}$

License: Creative Commons Attribution 4.0 International License (CC-BY 4.0). 


\section{ABSTRACT}

Empirical research has consistently demonstrated that residents of disadvantaged and racialized inner-city neighborhoods across North America are subjected to disproportionate and omnipresent policing. Consequently, relationships between law enforcement officials and marginalized community members are often strained. Whilst a robust body of literature has examined how citizens perceive "every day" policing practices such as "carding," stop and search, etc., it remains unclear how citizens perceive more invasive policing encounters - such as police raids. Drawing upon 35 interviews with residents of Toronto's inner-city, this paper explores how community members experience, make sense of, and talk about police raids. Our data uncover widespread perceptions of nefariously motivated police misconduct, raise questions about how residents anticipate and expect police to treat them, and highlight nuances in how these experiences shape police legitimacy views. We argue that how residents perceive police to behave during raids matters, as this can damage perceptions of police legitimacy for some residents, while merely reaffirming existing views for others.

\section{Introduction}

Concerns over police use of "carding," racial profiling, brutality, and lethal force against racialized minorities have increasingly dominated public discourse across North America in recent years, largely attributable to the Black Lives Matter movement (Lebron 2017; Rickford 2015). Alongside a disturbing list of racialized minorities killed by police, the killings of Breonna Taylor and George Floyd earlier this year in the United States ignited protests across the world and remobilized communities in the fight against racial injustice in policing. Research demonstrates that members of racialized groups, and Black men in particular, are subjected to disproportionate levels of police surveillance and abuses (Brunson \& Miller 2006; Weitzer 2017). Since policing practices also flow along class lines, such experiences are heightened for residents of marginalized and stigmatized inner-city neighborhoods (Anderson 1999; Goffman 2015; Stuart 2016). Consequently, racial minorities across North Americaparticularly those residing in inner-cities-oft view police negatively, report lower levels of trust and legitimacy in police, and even fear police (Cao 2011; Phillips \& Bowling 2003; Sprott \& Doob 2009; 2014; Wortley \& Owusu-Bempah 2009; 2011).

Much of what we understand about citizens' views of police is rooted within procedural justice literature. This scholarship argues that citizens' views are largely shaped by their perceptions of the quality of treatment they receive from police. When people feel they are treated fairly and respectfully - or with procedural justice - they are more likely to indicate higher levels of trust and confidence in law enforcement. Conversely, when people feel they are treated unfairly and disrespectfully-without procedural justice - they report lower levels of trust and confidence in the police (Tyler et al. 2014; Tyler 2003; Madon et al. 2017; Mazerolle et al. 2013; Murphy 2013; Murphy et al. 2017). Importantly, 
trust and confidence also contribute to citizens' assessments of police legitimacy, such that low levels of trust and confidence in police are associated with low levels of perceived police legitimacy (Gau \& Brunson 2010/2015). Therefore, it is perhaps unsurprising that relationships between police and racialized communities are often strained (Tyler 2003; Tyler \& Huo 2002; Madon et al. 2016).

The maintenance of police legitimacy is essential from a community safety perspective because community members are more likely to obey the law and cooperate with the police if they trust that the police take them seriously, treat people fairly, and perceive legal institutions as legitimate (Brown \& Benedict 2002; Hinds \& Murphy 2007; Jackson et al. 2012; Madon et al. 2017; Tyler \& Huo 2002). Research has found that this also applies to convicted criminal offenders; those who perceived the justice system to operate in procedurally just ways reported greater obligation to obey the law in the future (Baker 2017). Ultimately then, "the police ... can facilitate acceptance by ... treating community residents in ways that lead them to feel that the police and courts exercise their authority in fair ways" (Tyler 2003, p. 286).

Procedural justice research has reframed how scholars and practitioners understand police-citizen relations (Sarre \& Prenzler 2018). However, this literature is characterized by three tendencies. First, much of this empirical work examines the views of individuals with relatively little and/or infrequent contact with police at the exclusion of those with accumulated police contacts. Second, and relatedly, the bulk of these studies focus on how "pro-social," law-abiding citizens view and experience police encounters, excluding those who are (or whom police perceive to be) criminally involved (Baker et al. 2014/2017). - Third, research has typically focused on "every day" policing interactions, often omitting less frequent but more intrusive police contacts, such as police raids.

While "every day" policing encounters vary significantly based on race and class $\stackrel{2}{2}$ policing encounters that may not be considered "typical" or "every day" for any citizens - such as police raids-have routinely escaped scientific scrutiny. These predispositions have limited our knowledge $\underline{3}$ of how procedural justice or lack thereof might work for: 1) those with frequent police-contact; 2) those who are or are perceived to be criminally involved; and 3) those who have experienced more invasive police interactions. Consequently, we know little about how inner-city residents experience more invasive and acute police practices - such as police raids. This is surprising since the potential for negative interactions is likely heightened during more intrusive police interactions, and negative experiences have a greater influence on legitimacy views than positive ones (Skogan 2006).

Commonly deployed in many Western nations such as the United States, Canada, $\underline{4}$ and the UK, raids constitute one of the most imposing modern policing strategies, where oft paramilitary-style Special Weapons and Tactics (SWAT) $\underline{5}$ units enter a dwelling in search of a suspect or evidence. Many raidsspecifically drug-related ones-are designed to surprise residents; heavily armed teams may use 
battering rams and flash grenades when entering people's homes, compel everyone on to the ground, and often use force to ensure compliance, all before the search begins. Scholars have pointed to raids as a striking example of how police services have become increasingly militarized (Kraska \& Kappeler 1997), $\underline{6}$ with police militarization disproportionately utilized against racial and ethnic minority communities as a tool in the War on Drugs ${ }^{7}$ and "gangs" (Kraska 2007; Murch 2015). Though police generally do not share data on the prevalence and distribution of police raids, it is estimated that tens of thousands of homes are raided in America each year (Kraska 2007). $\underline{8}$ In Canada, SWAT deployment has increased by 2,100 percent over 37 years (Walby \& Roziere 2018), though we do not know where raids occur, whom they are deployed against, and what from a crime control, deterrence, or public safety perspective they yield.

Despite the fact that police services across the Western world are increasingly utilizing police raids (Fisher 2010; Roziere \& Walby 2019), this phenomenon has received little scholarly attention. $\stackrel{9}{ }$ While law enforcement officials have provided many rationales behind the use of police raids, including concerns over destruction of evidence, broader public safety, and hostage situations - all important functions - most studies examining police raids have interrogated the effectiveness of their deterrence-based outcomes. This body of work has argued police raids have little to no impact on reducing crime, particularly in the long-term (Cohen et al. 2003; McKeganey \& McGallagly 2013; Phillips et al. 2016; Sherman et al. 1995). $\underline{10}$

Therefore, we still do not understand how citizens experience these types of police encounters or whether/how these experiences influence their perceptions of police legitimacy (Tyler \& Wakslak 2004). Examining how individuals and communities experience, make sense of, and discuss police raids is important because direct and vicarious encounters with police have the power to shape perceptions and, consequently, impact levels of citizen compliance, willingness to cooperate, and even re-offending (see McClusky et al. 1999; Paternoster et al. 1997; Tyler 2004; Tyler \& Huo 2002; Brunson \& Weitzer 2009; Madon et al. 2017; Murphy et al. 2017; Urbanik et al. 2020). If police raids reduce perceptions of police legitimacy, these practices may undermine crime-control initiatives, negatively affect policecommunity relationships, and further erode resident trust in the police.

\section{Methods}

In the summers of 2016 and 2018, we conducted a study examining residents' perceptions of and interactions with police in three marginalized inner-city Toronto (Canada) neighborhoods: Regent Park, St. Jamestown, and Blake-Boultbee. We conducted 45 semi-structured and nine follow-up interviews with street-involved persons (30 male, 15 female, aged 18-74 years), examining how early and repeated police contacts throughout a person's lifetime impact police-community relationships in Toronto's inner-city. A remarkable number of our participants-35-reported experiencing at least 
one police raid. Hence, we wanted to examine participants' accounts and narratives of these experiences.

We drew upon our long-standing connections to and existing rapport with residents in these neighborhoods to recruit participants. This involved six years of ethnographic research in Regent Park for Urbanik (Urbanik 2017), and long-standing personal relationships for Greene. We recruited participants from our existing networks and relied upon snowball sampling to extend our participant base (Warren 2001, p. 8). We recruited participants with sustained interactions with police who lived in or had deep connections to the neighborhoods and involvement/intimate knowledge of the informal economy. Research has documented the importance of strong rapport with participants prior to conducting formal interviews (Venkatesh 2002). Given our participants' positionality, activities, and immense fear of police retaliation, we believe that our pre-existing relationships enabled trust and created an environment where our participants could speak openly and honestly about their experiences with police. This rapport also allowed us to challenge participants and triangulate our findings. In addition, we spent long hours hanging out with participants in their respective communities.

We interviewed participants in various locations across the neighborhoods, including park benches and front porches, cars, and residents' homes. While we initially used a semi-structured interview guide, the interviews became more open-ended over the course of the study. We pursued new themes as they arose until we reached thematic saturation (Guest et al. 2006; Small 2009). Interviews ranged from 20 minutes to several hours, averaging 1 hour, and participants were compensated $\$ 30.00$ for their time.

Interviews were audio-recorded, transcribed, and anonymized. We applied deductive and inductive thematic analysis, allowing our interview data to guide theme development and identification that were recurrent throughout interviews (Braun \& Clarke 2006; Charmaz 2011). The analysis was ongoing and staged throughout data collection phases. Additionally, we immersed ourselves in the data at each stage by re-reading interview transcripts multiple times to identify initial free-codes. With the help of research assistants, both authors created a comprehensive coding scheme. In the initial stages of coding, we developed six main codes (e.g., perceptions of police, neighborhood-specific knowledge, and police raids). In the second stage of coding, we further analyzed the data into 17 sub-themes based on our main codes (e.g., perceptions of police misconduct and racism, experiences of police violence, willingness to report misconduct, and positive interactions with police).

Initial tests for inter-coder reliability were completed by having each author and two research assistants independently identify main codes and sub-codes for a set of five interviews. These initial reliability checks resulted in $90 \%$ agreement on all main/sub-codes. Following best practices (Braun \& Clarke 2006), after initial coding was completed for all interviews, we again reviewed the interview 
transcripts to ensure all relevant data were explored in relation to these codes. We then refined themes and sub-themes within this context. Finally, the authors then independently reviewed the interview transcripts to ensure that each of the main/sub-codes reflected participants' views accurately and that the quotations selected to represent the main/sub-codes were representative of the data. Once all interviews were coded, the authors conducted a second round of reliability checks. All coded interviews and selected quotations were independently assessed as to how well they related to the themes and sub-themes. These final checks resulted in complete agreement on the quality of the quotes as they related to their representation of identified codes and sub-codes.

This paper draws upon data from 35 interviews, and 9 follow-up interviews with participants who resided in or had deep connections to Regent Park and/or St. James Town and experienced at least one police raid ( 23 males; 12 females). $\underline{11}$ of this sample, $79.4 \%$ were Black ( 22 male; 5 female), $11.8 \%$ Indigenous ( 1 male; 3 female), and $8.8 \%$ were white ( 4 female). Almost all of our participants resided in social housing when they were raided, were considered low income, and received government financial assistance. Some of our participants were the suspects of the search, while others became caught up in the raid because they either lived in or happened to be present in the home that was raided. The vast majority of our participants reported that the raids related to drug trafficking investigations, with a smaller number focused on guns and/or gathering evidence in robbery cases. Our participants spoke of dated experiences (some as far back as 1994), as well as of more recent ones, including raids that happened days before our interview. At times, remnants of the raid were still visible, including police tape and stickers on doors, broken doors, disordered contents, and slashed couches.

\section{Setting}

Our study takes place in Canada's largest city-Toronto-the epicenter of the country's police legitimacy crises. Whilst many Torontonians pride themselves on living in the most multicultural city in the world, residents of Toronto's most marginalized neighborhoods-and Black Torontonians in particular-have long expressed concerns about the Toronto Police Service's (TPS) alleged mistreatment, including accusations of police racism, racial profiling, police violence and misconduct (Jackson 1994; Meng 2017; Urbanik et al. 2020; Wortley \& Owusu-Bempah 2011). Only in the face of mass protests, however, have these strained relationships been acknowledged by public officials, with the mayor criticizing the "unacceptable level of distrust" between Toronto's most disadvantaged neighborhoods and the police (Armstrong 2015, p. 1), and a former Deputy Police Chief admitting he had "never seen policing at this low a point in terms of public trust and legitimacy"(Powell 2016, p. 1). Though formal charges relating to misconduct are rare, several TPS officers were recently investigated and/or found guilty of theft, perjury, evidence planting, assault, and attempted murder (e.g., Edmiston 2016; Fox 2018; Gillis 2020; Katawazi 2019; Loriggio 2020; Pazzanno 2019). 
In Toronto, over-policing, police abuses and misconduct, and fear/distrust in police are felt most acutely in Toronto Community Housing Corporation (TCHC) neighborhoods; social housing areas often mirroring American-style projects (Berardi 2018; Greene et al. 2020; Urbanik 2017; Urbanik et al. 2020). Data for this paper stems from two of these neighborhoods, Regent Park and St. James Town. Information on TCHC properties and race/neighborhood crime statistics $\underline{12}$ is severely limited, though many Torontonians consider TCHC projects dangerous spaces. Apart from being territorially stigmatized and symbolically denigrated (Wacquant 2010), TCHC projects comprise some of Toronto's poorest and most racialized neighborhoods and are disproportionately afflicted by gun violence and homicides (Davis \& Appleby 2011; Freeze 2014). As such, many residents, specifically young Black men, live in fear of violent victimization, particularly since historical and ongoing allegations of police misconduct have pushed many to distrust, avoid, and circumvent police altogether (Berardi 2018; Urbanik 2018). Neighborhood context plays a key role in perceptions of and experiences with law enforcement, particularly for members who reside in marginalized and racialized neighborhoods. These residents draw upon the nature of policing in their cities and neighborhoods-including their own and vicarious experiences with police - to determine their satisfaction with and trust in police (Anderson 1990/1999; Nagin \& Telep, 2017; Tyler \& Wakslak 2004).

Developed in 1948, Regent Park is Canada's oldest and one of its largest and most stigmatized social housing neighborhoods. Prior to starting the area's ongoing revitalization, $100 \%$ of the community was devoted to social housing. At present, Regent Park is home to approximately 11,000 residents as it continues to undergo poverty deconcentration via "social mixing" (City of Toronto 2016). Despite this, Regent Park's poverty rate and proportion of low-income residents are double the City's average (City of Toronto 2018, p. 3). Sixty percent of those under 17 years old and 40\% between 18-64 years old live in poverty (City of Toronto 2018]. $\underline{13}$ The neighborhood continues to be highly racialized, with $70 \%$ of residents identifying as visible minorities (City of Toronto 2018). $\underline{14}$ Ethnographic research has uncovered that Regent Park continues to be afflicted by crime and violence and that the revitalization has diminished the protective elements of its operative street code, heightening residents' safety concerns (Urbanik et al. 2017).

A short walk from Regent Park is St. James Town, Canada's most densely populated neighborhood. The area is home to 18,615 residents (City of Toronto 2018), and though the neighborhood is socially mixed, it is well known for its high-rise apartment towers where many public housing tenants reside. Many residents face poverty and racialization, with $40 \%$ living at or below the poverty line, almost $67 \%$ identifying as visible minorities, and almost 50\% being immigrants (City of Toronto 2016). Apart from over-crowding, residents have characterized the neighborhood as highly neglected, having limited social and community services, and dotted with decrepit buildings (Barnes 2011). Further, many have reported experiencing systemic racial and economic discrimination (Karamali 2020). 
Given the severe disadvantage that comes with living in TCHC projects and residents' many social and economic struggles, several of our participants buffered their incomes through illicit means. Most of our participants were or had been, criminally involved, though a small number had moved away from "the life". Male participants tended to be involved in serious crime such as drug and gun trafficking, robberies, and gang violence. About half of female participants ran their own enterprises of illicit income generation (e.g., drug trafficking, working as "set up" girls, running trap houses $\underline{15}$ ), while the others reported playing a more supportive role in their romantic partners' criminal endeavors (e.g., storing drugs/guns). Most of our participants had frequent and sustained contact with police starting at a young age, though a few did not have official charges or convictions before (or even post) their raid experience. Grounds for the raid also differed (e.g., searches for drugs, firearms, or a suspect), with the majority of our participants reporting that they were raided for drug investigations.

\section{Findings}

Our participants understood that raids $\underline{16}$ were not intended to be pleasant police interactions. They recognized the need for police officers to assertively establish safety (securing scene and removing persons with handcuffs, etc.) and knew that their property would likely be left in disarray and possibly seized. Though we expected participants might be upset about being raided and/or the legal consequences of the raid (charges and legal seizure of drugs/cash), participants' narratives rarely focused on these issues. Instead, accounts revolved around how they and their property were treated. Recounts centered upon officers' alleged behaviors during the raid, and specifically, upon perceived instances of police misconduct. Our findings revealed that it was not the predictably unpleasant elements nor the legal outcomes of police raids that influenced our participants' views and experiences of police, but perceptions that police acted without procedural justice: including warrantless searches, unnecessary violence and destruction of property, and illegal seizures/"robbery". This is consistent with procedural justice literature which demonstrates that it is the quality of treatment that citizens receive by police (and other criminal justice officials) and not the outcomes related to these interactions that shape perceptions (Tyler \& Huo 2002; Sprott \& Greene 2010). Notably, all participants reported experiencing at least one form of police misconduct, with the majority reporting experiencing multiple forms.

Our findings demonstrate that for many, experiencing a police raid intensifies negative perceptions of police and further diminishes already low levels of police legitimacy. However, the extent to which perceptions of police misconduct impacted legitimacy views depended upon participants' expectations of how police would treat them. More specifically, while many of our participants characterized police behaviors during raids as particularly influential on their perceptions of law enforcement, others expected such police actions, and therefore, these behaviors minimally impacted their views of police legitimacy. 


\section{Perceptions of raid legality}

While all participants believed that police needed to produce a search warrant upon entry, several alleged that this did not occur, while others reported that police provided warrants for some raids, but not for others. Consequently, many of our participants believed that police officers entered and searched their premises illegally by entering their homes without a warrant and/or refusing to produce a warrant when asked. $\underline{17}$ For example, in describing the early moments of the raid on her apartment, Michaela $\underline{18}$ (Black-female-4lyrs) explains what transpired when she asked police to produce a warrant: "So you guys [Police] are coming in my house? Like, I need a warrant. I need that paperwork, you know? ...He [Police Officer] was like 'We don't need a fucking warrant! We don't need a fucking warrant!" and I was like “Um, excuse me? Yes, you do!"

Under Canadian law, police are required to attain a search warrant prior to a raid, follow the Knock and Announce doctrine (KA), and present the warrant to occupants. However, the law recognizes that in limited cases, exigent circumstances may preclude the legal necessity to obtain a warrant in advance of a search. Though the law has recognized exigent circumstances as: concerns over the wellbeing of those in the premises, evidence destruction, and suspect flight, at present, no-warrant raids are generally reserved for situations where there are grounds to believe there is a threat of harm. While these legal provisions allow officers to conduct raids without prior judicial approval, they are subject to scrutinous legal determination that the search was legally "reasonable" should the case go to court. The burden is on police to justify why this type of entry was necessary (see Canadian Charter of Rights and Freedoms s.8; Canadian Criminal Code s.320.29 and 487; Controlled Drugs and Substances Act s.11).

While police may have been justified in entering Michaela's home without a warrant, she believed they were required to have one and to explain the grounds for the search. LeShawn (Black-male-29yrs) also perceived that the police entered his home illegally: “They didn't show us any warrant, they didn't show us anything." Additionally, when participants saw a warrant, many reported officers were reluctant or delayed in presenting it, making residents (temporarily) feel the raid was conducted illegally:

When I caught my breath and realized what's going on [being raided], wait a second, Do you guys have a search warrant? What are you doing here? Aren't you supposed to show it to me? Then they're like "We don't have to show you anything" ... I seen nothing. So right at the end just before they left, the guy came and put the piece of paper [warrant] down on the table. (Dana, Whitefemale-39yrs)

Another participant, Bianca (White-female-36yrs) described a recent situation where officers allegedly deployed the same warrant for two raids of her home, which she believed was illegal. She described her conversation with the lead detective: "He's kind of pissed off right now because whatever 
happened could really fuck up his shit. He can't execute ONE warrant TWO times." The deep distrust of police and persistent perception of illegal, warrantless searches was evident even in cases where defense lawyers had indicated to our participants a warrant had indeed been issued: "I don't think it was real [warrant]. I never physically seen it myself. My lawyer said he seen it ... it didn't exist and they're trying to hide that fact. They came here without a warrant" (Addy, Black-female-27yrs). The importance residents placed on seeing warrants for themselves was critical to their assessments of raid legality. Consequently, residents might conceive of legal raids as "illegally" conducted if officers do not present a warrant in a timely manner.

Though police must prioritize securing the scene and ensuring their safety at the onset of a raid, as opposed to immediately presenting a warrant where one exists, officers should strive to produce the warrant as soon as the scene is secure. Failing to do so may agitate occupants as they may feel police are disrespecting them and conducting an "illegal" raid. In circumstances where police do not have a warrant, officers should clearly communicate why a warrant is legally unnecessary, explain the reasons for the search, and that a Court will later determine if the raid was legally justified. By doing so, police may be able to effectively limit perceptions of police misconduct and improve police-resident relationships, thereby potentially increasing occupant willingness to cooperate with police during, and after, the raid.

\section{Perceptions of unnecessary violence and damage}

Our data reveal that irrespective of the perceived legality of the raid, many participants reported police behaviors they perceived to be far beyond "acceptable" or "necessary" raid elements. These alleged forms of police misconduct included: perceptions of unnecessary violence, destruction of property, and unlawful seizure. All of our participants recognised the need for police to secure them and the scene for safety reasons, as John (Black-male-31yrs) claimed: "[Police] just make sure no one has weapons, make sure, you know, get everyone out the house. Just want to make sure everyone is safe, that they don't get hurt right? I don't blame them." Despite acknowledging officers' need to exercise caution, our participants felt that police frequently used a disproportionally higher level of force than necessary. For example, Jamieson (Black-male-22yrs) described his experience when the police came to his house, knocked and covered the peephole:

He [Police Officer] says “It's the police." I says, “I don't believe you, I want to see your badge, what's your number?" And then I hear [crow] bar banging on the door like they want to break it. And then like, just banged down the door! Came inside and put me in handcuffs. I had my hands on my back and they pinned me on the floor and the cops stomp me on the back of my head. And my chin was like this [indicates angle] and they opened up [cut] my chin. 
When we asked Jamieson if he was resisting, he replied: "I was in fucking handcuffs and they were knocking [punching] my head! Are you fucking kidding me?" Another participant, Bruce (Indigenousmale-33yrs) had his home raided as part of a "gang" blitz, where over 20 alleged gang members were arrested. He described the early-morning raid:

The whole task force comes in, flash grenade my house twice. They tell my friend Holly to get on the floor, so she gets on the floor ... they tell me to get on the ground. And they're swearing, yelling, being mean and then they said, "Do you have any weapons?" I said, "Well I got a small knife in my left pocket." ... Then four of them jumped on me, just threw me down and started hitting on me and shit ... my face was bloody, my shirt got all ripped, torn apart. Then they dragged me down my stairs and put me in handcuffs on a chair in the hallway.

In their accounts, our participants did not seem affected by behaviors they considered standard-or acceptable-during raids, such as being physically searched or arrested. Instead, their narratives emphasized what they perceived as superfluous and unnecessary police violence, given they were surrounded and in handcuffs when these altercations allegedly occurred.

Another central theme in our data was participants' perceptions of the unnecessary destruction of their home and/or personal property during the raid. Our participants understood that a raid would involve searches of their belongings for contraband/evidence and some damage as a result (e.g., searching within sofas or walls), but were deeply distressed by the seemingly needless damage allegedly caused by police. As Dana highlights, "I know they are going to do a search, I've been there enough times. I know you going to look in shit, behind vents, lights. But do they have to destroy my fucking lights and drawers and shit?" When describing the state of his apartment when he re-entered after the search, Mikey (Black-male-40yrs) explained: "They took the picture off the wall and left it on the ground. It looked like they stomped on it. They had to have flung it across the room to break it down like that. It's not like they opened them and accidently stepped on one. They were all smashed to pieces." Stella (white-female-47) was particularly upset about how police allegedly treated her belongings:

My house was just a mess, you shoulda seen it. They broke things, they fuckin' poured shampoo on stuff ... They would look through stuff and throw it in this plastic bin I had. And then they ... poured shampoo on it for no reason. They put my clothes in the toilet! For what reason? I have no idea.

Miranda (Indigenous-female-4lyrs) described a similar situation: "I had a whole bunch of glasses in the house, they stepped on all them! Sunglasses. Raybans, Oakleys, Dolce and Gabbanas. ... Stepped on all my glasses." Even more troubling, she claimed: 
They demolished the whole house! They demolished the kids' room. The kids had a rabbit, they even looked in the rabbit cage and the food and stuff. The rabbit was found dead on the side of the bed at the wall. It's crazy. This is what they do.

Participants believed police intentionally and nefariously caused this additional property damage, as Dana contended: "They enjoyed it. They got satisfaction from it. It was like they had a personal investment. They should just do their job, not shit on you [hurt you] as they smash all your belongings."

\section{Perceptions of the legality of property seizure}

The most prominent theme in our data was the perception that police officers "robbed" or "stole" from participants during raids. Almost all of our participants accused police of "stealing" items from their home, which they claim to have either witnessed or discovered after police left. Stolen possessions referred to those that police allegedly took without recording or did not accurately record in official documentation $\underline{19}$ such as cash, drugs, jewelry, concert tickets, designer clothes, and handbags-though money and drugs were reportedly "stolen" most frequently. To illustrate, Tyke (Black-male-22yrs) explained how police allegedly "stole" money from his apartment during a raid: "They found money in a vent and they took it and never reported it." Since the money was removed but not documented, Tyke was particularly distressed because he had no remedy for retrieving his cash in the way he would if the money was legally recorded 20 : "I've never been straight up robbed like that, like bold faced! You know what I mean?"

Participants who were raided multiple times reported frequently experiencing such situations. As Joe (Black-male-36yrs) claimed: “They come to raid your house, they take everything. They don't jot it down [formally report the seizure] either ... They took my chain before [previous raid]. Now they took $8 \mathrm{G}$ 's $[\$ 8,000]$... To tell you the truth, I probably got robbed from the police (laughs)". Similarly, Marco (Black-male-26yrs) described a raid on his mother's house, where his brother was the suspect in the search: "They took money...out my safe one time ... Took fuckin' 30 grand out of my safe, they left 8. " Marco clarified that although the police took his money, he was charged with an offense unrelated to the investigation. He explained learning about the missing money afterward: "They didn't mention nothing about the money ... I didn't know nothing about my money until I came back out [released from jail]." It is possible (though perhaps unlikely) that some participants misunderstood the seizure process, interpreting legally-seized items as "stolen." To limit confusion, police should ensure that they clearly explain the legal process behind asset seizure and remedies for property recovery.

According to our participants, when police officially seized property-specifically money/drugsofficial seizure documentation often intentionally misrepresented the quantity taken from the home and/or did not include all items seized. .11 As Derek (Black-male-32yrs) posited: “They say they took THIS amount of money out of your house and next thing you know they're saying a different number 
of money." Laudia (Black-female-21yrs) described a similar situation: "They'd confiscate money at a raid, and then when you got to the station, there wouldn't be what there was at the house." Further, participants explained that the proportion of money officers "illegally" seized varied depending on their legal [documented] yield: “Depending on what's confiscated in the raid. If it was just a small amount, then just a small portion would go missing, right? But sometimes they would go up to 10 grand, 15 grand, and half of it would go missing" (Jason, Black-male-24yrs). Laudia also highlighted this variation: "Sometimes half, sometimes just a third, just depending on how much money they [police] got."

All of our participants who reported that the police had "stolen" money (and sometimes drugs and other items) from them believed this was for disreputable reasons-namely, personal gain for police officers. $\underline{22}$ For example, Jay-Juan (Black-male-28yrs) explained: “If they claim it's been seized then they don't get that money. The reason they take it and not say it [officially report], cause they could keep the money then, and the drugs." Seana (Black-female-20yrs) describes police finding an ounce of weed and a few thousand dollars during a raid "and when they [police] bring it in [officially seize] they're only claiming half of that money, so where the other half gone? In their pocket!" Similarly, Kurtis explained where he believed his missing money went (Black-male-25yrs):

Mike: They probably split it down as much they can, between each other. Everybody gets lunch money for the week.

\section{I: That's a lot of lunch money.}

Mike: Yeah, well you have to remember though, it's like ten of them that come on a raid, right?

Interestingly, participants believed the discovery of firearms in the home increased the likelihood of police accurately documenting seizures. Calum (Black-male-44yrs) argued, "If there is money and no guns, they're taking the money and leaving it alone [not documenting seizure]. If there is guns and money they're like, "fuck we gotta do our job now" [formal seizure]." Devon (Black-male-29yrs) shared this view and explained why:

I never heard of a man say his house got raided and he had a gun in the house and [police] didn't claim it. Usually they want to claim something like that ... not only cause they could charge you but that ups your ranking in the police force as an officer. The only thing that they don't really claim is money, the least other than that would be like drugs.

Our participants also believed the police would sometimes attempt to cover up their misconduct. As Ricky (Black-male-31yrs) explained: 
They [police] basically searched one room. One room! They didn't search the living room, they didn't search the washroom, they didn't search the kitchen. They searched the bedroom, where the safe was! Tore that room up like it was a tornado, broke things, broke the dressing table, broke everything ... and let Veronica [girlfriend] in. Now she's looking for the money that was in

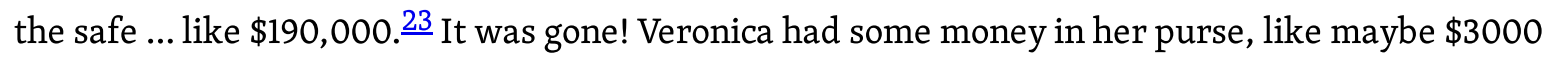
in different purses combined, that's gone too ... All the cop said was he found $\$ 97$ on the dressing table, but she didn't have $\$ 97$ hanging around somewhere. So, clearly they put $\$ 97$ on the table so it looks realistic and took [officially reported] that.

Similar to other participants, Ricky perceived the police raid to be a coordinated "robbery" of his home:

You're there looking for drugs, you're looking for weapons and you search one room in an entire house?! So clearly you knew the money was in the safe, you went there, and you got the money out the safe and "Here's your search warrant and left." They basically went there to rob us and that's exactly what they did!

\section{Glimpses of respect?}

Despite broadly negative experiences of police raids, participants identified moments where they believed police treated them comparatively well. For example, though Addy was upset about allegedly being "illegally" raided, she spoke highly of the lead investigator: "So, I'm on the phone calling frickin the Guns and Gangs guy. He helped me as much as he can, you know what I mean? That's one thing I'll say to you, his name was Thomas. He was the head guy for Guns and Gangs, he was outstanding." While police knocked down her door and seized firearms, Addy reported they respected her belongings: “They didn't rip my apartment or nothing, though. Nothing was out of place. Even my pot was still where it was when I left ... it looks like they even cleaned up the place, you know? (laughs)". Another participant, compared her most recent raid experience with a previous one, recognizing a marked improvement in how police treated her: "They [police] were really nice, you know? Like the way they treat me was different" (Aliyah-Black-female-22yrs). $\underline{24}$

Even when police allegedly engaged in misconduct, participants recalled situations where they were grateful for police respecting them and their property. To demonstrate, while Danny described officers using "unnecessary" physical force at the onset of the raid and allegedly 'stealing' his wallet, $\underline{25}$ he was surprised and relieved at the "minimal" collateral damage from the raid: "Surprisingly, even my beers were there. I had 50 beers still there. I had a freezer full of meat and that was still there. And they didn't even cut open my couch ... I had a big $\$ 3000$ couch". Stella explained that while police "unnecessarily" damaged her property, there were moments when police were "nice" even while using physical force: 
I: What happened when the police came in?

R: Oh ... fuck. They just ... "POLICE! POLICE! AHHHHH!! DON’T MOVE! PUT YOUR HANDS OVER HERE!" (laughs). And there was one girl [female officer], and she was like, your size. And my first reaction is to hit! Because they're throwin' you around, you know? And it was her, and she was so little. And I'm thinkin', I better not hit that bitch, she'll kill me! (laughs)

I: She was pushin' you around?

R: Well, yeah. But she was nice about it. Like, after the initial, you know, "What the fuck's goin' on?" ... She threw me down-but she threw me on my bed. Which was nice because I'm old and it would hurt(laughs) ... and then she was really nice about it, you know?

I: What was she saying?

R: Just, you know, "We have a warrant" and blah blah blah. I said, "Well you could've told me, you coulda just knocked on the door, I woulda let you in." Like, what the hell? ... But she was nice about it, you know? And the other cops were too.

Given their oppugnant orientations, some might assume criminally-involved persons unequivocally loathe the police. Our data reveal per contra; when criminally involved persons believe they have been treated fairly and with respect they can and do speak positively about police. Our findings further uncover that while negative raid experiences impact police views (as we demonstrate below), positive police-encounters are not forgotten, even when they are outweighed by negative ones. However, these glimpses of fair/respectful treatment are unlikely to improve broader police legitimacy views within a context of predominantly negative experiences (see Skogan 2006).

\section{Impact on views of police}

Some participants reported that raids negatively affected their views of police, and specifically, their willingness to interact and cooperate with them in the future. Though many already held relatively negative views of police, perceptions of police misconduct during the raid exacerbated this:

Even though before I was apprehensive about dealing with police ... I thought at the end of the day ... they wouldn't walk into someone's house and brazenly take that money. So now, even unconsciously, right away, I would cross the street or move away. I wouldn't want to be in the same vicinity with a police officer. Whereas before, I would be like "whatever I don't really care." As much as I didn't really love them, now I really hate them! I would never call the police under any circumstances unless my daughter was abducted. I would never deal with the police in any way unless I absolutely have to. (Dana) 
[Trust,] that's totally gone. For safety of my kid? Yeah, I would [call police]. But like for me? No! (Teaya-Indigenous-female-27yrs)

I think about it all the time [the raid]. This guy tried to break in my house a couple months ago-I didn't call the police. I didn't know what to do. I don't want them [police] in my house, I didn't want to go through that again. I would rather a stranger break in my house and kill me then fucking have that happen [again]. That's my mindset, they traumatized me more than anyone ... I'm traumatized and I don't trust you guys. $\underline{26}$ (Allegra-White-female-28yrs)

As evidenced, participants' experiences of police raids deterred them from contacting police in the future. This consequence was so profound for Allegra that she refused to call the police even in the face of her own potential victimization. This raises critical questions about how perceptions of police misconduct can place inner-city residents at risk of additional harms, potentially propelling the cyclical nature of inner-city violence and victimization (see also Anderson 1999). Critically, Devon highlights how perceptions of police misconduct may negatively affect community willingness to cooperate with law enforcement: "Then you want to go to their family and be like "Well, I'm sorry" [about the raid] and then ask for information. They're not going to fucking tell you shit!"

However, the impacts of raids on perceptions of police were also related to our participants' prior experiences with law enforcement and resident expectations about how police behave and would treat them. For example, when we asked Ricky - who reported a long history of experiencing police misconduct - whether the alleged misconduct during raids impacted his views of law enforcement, he replied:

I don't think searches had anything to do with forming my view of police. As to the fact that I expect that from them at some point. Because nobody trusts the police to do their job lawfully in low income neighborhoods. So no, searches didn't change my views toward them punks.

Residents like Ricky, who had experienced multiple raids and held exceptionally low perceptions of legitimacy "expected" police to engage in misconduct during raids. Therefore, such experiences did not notably impact these residents' perceptions of police, given that they "knew" and were prepared for what police were "capable of." Instead, these instances only served to reaffirm existing views, which unmasks the complexities of police legitimacy views and the depth of damage caused by previous experiences.

Our data further show that participants perceived police actions during the raids as part of broader organizational corruption. Residents likened this system to organized crime and believed it was intended to harm them further. As Dana expounded: 
They [police] leave you with this feeling that they are just there to punish you. It was unnecessary brutality, insensitivity, cruelness and disregard for the situation. It showed me they [police] really do have a mob mentality ... I really saw the human side of them [during the raid]-acting like angry kids not professional police. They're a mob that wants to bully and intimidate.

While all of our participants felt that "good" cops existed, they simultaneously believed that 'good' officers would eventually be corrupted by police culture:

They all work together. So, if you're a new cop and you grew up your whole life like you wanna be a good cop, and you get into the divisions and find out you're working with a bunch of slime balls, a bunch of pieces of shit that's robbing people, but they show you how lucrative that could be. First of all, how do you turn down the money? Even if you do turn down the money, can you? Because the other cops will team up and shun you and deal with you fucked up [mistreat you]. So, it's like you have to go along with their thing [misconduct] or else you're on the outside. (MylesBlack-male-33yrs)

For that many police officers to all be in cahoots and know what's happening? I just imagine all the other people they've done this to ... these officers know what the officer was doing. It made me lose faith in police as a whole. Maybe ya, there is one or two good police, but how am I gonna tell who is the good police and the bad police? (Dana)

Relatedly, few participants attempted to officially report allegations of police misconduct during raids. $\frac{27}{}$ Those that did described the outcome as further reifying perceptions that "cops are dirty" and cannot be trusted. For example, Michaela described the futility of her effort:

His [her boyfriend's] lawyer said that we should charge the police and we both weighed the pros and cons. And it was explained to us that even if they were found guilty we would probably never get the money back ... we decided that it's better not to charge them with anything. Only at the trial I brought it up. "The police stole the money," but they denied taking anything at all. ... So the police stole the money from the house and at trial they denied finding any money on him, finding any money in the house, aside from finding $\$ 5,000$ in the house which I disclosed to them.

The impact of such misconduct heightened negative views of police, but also spread distrust to the wider criminal justice system. Ricky explains the effects having property "stolen" by police: "When something like that happens, how can you believe in the system? You can't believe in any part of the system!". This is consistent with research that demonstrates a "spillover" effect of perceptions of legitimacy between police and the courts (Baker et al. 2014).

The misconduct alleged by our participants during raids was described as motivated by personal gains (e.g., officers keeping all or portions of money found) rather than broader organizational gains (e.g., 
evidence planting). That none of our participants recounted evidence being planted/manufactured during raids (though this was reported during street interactions, see Urbanik et al. 2020) in order to drum up false charges is curious, as researchers have documented widespread perceptions of "noble" cause corruption in non-raid settings (Skogan \& Meares 2004; Urbanik et al. 2020). Despite debates about the prevalence, variability, and visibility of police misconduct (Son \& Rome 2004), our findings indicate participants perceived widespread corruption during raids via officers who raided them "illegally," used unnecessary violence, intentionally damaged their property, "stole" belongings, and the complacency of "uninvolved" officers who did not intervene. Scholars have argued that such phenomenon result from systemic issues within policing culture and are perpetuated through officer socialization (Marche 2009; Punch 2000; Skogan \& Meares 2004). The prevalence and consistency of these narratives across neighborhoods and participants' narratives should push us to reconsider the common "bad apples" explanation. Even if only a fraction of these allegations are true, police misconduct in Toronto's inner-city may be symptomatic of "bad branches" (sub-units) or "bad barrels" (entire services) (Ivković 2009), and raises important questions about how police-community relationships can be improved.

The damage caused by experiences and perceptions of police misconduct is striking and extends beyond individuals with direct experiences (Urbanik et al., 2020). As Chan and Chunn (2014, p. 74) write, "the use of illegal acts in policing the spaces of the inner city to control a marginalized (and often racialized) population has far-reaching consequences for individuals, communities, and police forces alike." In addition to affecting individual perceptions of, and therefore future interactions with law enforcement, how police were perceived to behave during raids further denigrated policecommunity relationships, as residents shared their experiences with others. To demonstrate, those in our larger study sample who had not experienced a police raid all knew someone who had and were aware of alleged misconduct during raids. According to Myles, such stories "get passed around. And even if it gets better, we're still gonna be telling each other."

Further, participants cautioned their experiences had broader implications, specifically that stories about police misconduct may instill and/or reinforce defiance in some community members: "If they keep doing that to the community, what they actually do ... is they're breeding more criminals. Even if a kid is not a criminal, they [police] don't understand that shit makes them into a criminal because it becomes "us" and "them" [police]. A good kid can become a criminal because he feels like it's me against you [police] now"(ShawnTay-Black-male-23yrs). ShawnTay's concerns about negative effects on crime control have scientific merit; when members of racial/ethnic groups suffer perceived injustices by police, these feelings can produce and encourage unwanted and damaging behaviors such as criminal involvement and aggression (LaFree 2018; Tonry 2010; Tyler 2005). Direct and indirect experiences with police that are seen to be unduly aggressive, damaging, etc. may further alienate community members - particularly racialized inner-city residents - thereby inadvertently 
perpetuating a cycle of crime and discouraging desistance (Anderson 1999, p. 318, 321). Said differently, we know procedurally unjust treatment significantly lowers offenders' feelings of obligation to obey the law (Baker 2017). Thus, perceptions of police misconduct and abuse may exacerbate crime by reducing the likelihood that offenders will (re)integrate into society.

\section{Discussion}

Presently, many law enforcement agencies across North America are striving to build trust with marginalized communities. Official police rhetoric is characterized by public relations promises that police services are committed to increasing transparency, accountability, improving citizen treatment, and eliminating discriminatory practices. In addition, many law enforcement agencies have embraced enhancing perceptions of procedural justice (if not, actual procedural justice) as the "silver bullet" for improving strained police-community relationships. However, since the bulk of empirical work on procedural justice has focused on "every day" policing encounters, little is known about the effect of more invasive policing practices - such as police raids-on perceptions of procedural justice. To the best of our knowledge, this is the first empirical study to comprehensively examine citizens' experiences of police raids and their influence on perceptions of police legitimacy.

Our data demonstrate that how residents perceive police treat them and their property during police raids matters. The very nature of raids (and the risks for all involved) is unpleasant and anxietyprovoking. However, participants' accounts centered upon their perceptions that police did not adhere to legal and professional standards of conduct during the raid, rather than experiencing a police raid per se and/or the legal consequences it may have invoked. We found that perceptions of police misconduct during police raids can erode police legitimacy, thereby further harming police-community relations. As evidenced, perceptions of police behaviors during the raids often (but not always) departed from participants' expectations of how police should treat them and their belongings, notably with respect and adherence to the law. For many, such experiences eroded trust and further delegitimized police, rendering participants less likely to interact and cooperate with police in the future.

If law enforcement agencies are committed to improving perceptions of police legitimacy, then their interactions with citizens during more intrusive encounters cannot be overlooked. Adhering to principles of procedural justice and ensuring residents see the raid process as legal, transparent, and not causing additional harms may be an important component of improving trust with marginalized inner-city residents. Certainly, treating people fairly and with respect during a single event like a police raid is unlikely to solve the problem of low levels of trust and legitimacy in police, since perceptions of police are accumulated over a lifetime (see Nagin \& Telep 2017; Tyler 2017). Nevertheless, even within a lifetime of personal and/or vicarious experiences with police during less invasive encounters, highly intrusive events - such as police raids - where residents perceive they are 
being mistreated can negatively impact their views of and future interactions with law enforcement. While police may not be able to effectively increase their legitimacy within a community through a single procedurally just encounter within the context of a police raid, behaving in a procedurally just manner would likely not further damage their reputation or compromise their trust-building efforts. Our data reveal that even during undesired police interactions, such as raids, citizens can and do recognize when officers treat them well. Further, research indicates that when police treat citizens fairly and with respect, this can encourage cooperation and hinder criminal offending (Sherman 1993).

There may be an opportunity for police to improve trust with disengaged citizens, such as those living in marginalized communities, through increasing perceptions of procedural justice during police raids. For example, in instances where participants may have misunderstood legal requirements with regard to warrant presentation or property seizure, police should thoroughly explain the process to them, which may prevent such confusion. Whilst this may seem counterintuitive-given that our sample was comprised of criminally involved individuals who are often perceived to be inherently anti-policerecent research suggests that those who are most disengaged in society are most apt to benefit from procedurally just treatment (Madon et al. 2017). Further, since increasing police legitimacy may decrease criminal involvement and increase willingness to cooperate with police-widely recognized problems in many inner-city communities - the potential benefits of critically examining and addressing perceptions of police behaviors during police raids cannot be understated. For these reasons, raids may be a surprisingly opportune time for police services to demonstrate respect for citizens, adhere to professional and legal standards, demonstrate intolerance for misconduct, and enhance residents' understanding of police procedures.

Our interviews catalog a sustained and detailed inventory of alleged police abuses during home raids. Since Canadian police are often considered "better" than their American counterparts (Ayoyo 2018) and limited research examining inner-city policing in Canada exists, our participants' accounts may be surprising and may raise questions about truthfulness $\underline{28}$ (insert endnote 28). Our study was designed to capture narratives about and perceptions of police raids. Narrative criminologists have urged scholars to examine narratives and stories-irrespective of truthfulness - since stories, and not necessarily "facts" influence how people behave (Presser 2009/2016; Sandberg 2010). Consequently, if residents perceive that the police engage in the gross instances of police misconduct described aboveeven if they do not-their perceptions of police as illegitimate and untrustworthy will shape and inform their future interactions with police. Given this, it ultimately matters little whether our participants' narratives are truthful as these narratives are shared amongst residents and shape their own and others' perceptions of, and therefore future police encounters.

However, given that members of marginalized communities are often doubted in favor of official claims, we find it imperative to comment on the credibility of the narratives contained herein. First, 
both authors have long-standing relationships with many study participants and were able to draw on an existing rapport to elicit, probe, and push back against participant narratives. Second, we asked participants open-ended questions about their experiences with police throughout the life course (including with raids). In all of our interviews, participants described positive police interactions in addition to negative ones, a counter intuitive approach if they desired to broadly delegitimize/slander police. Third, narratives were rich in detail and included precise locations, times, what they were doing prior to/post interactions with police, others present, criminal activities, and quantities of cash and types of drugs/firearms. Research has found that when individuals fabricate stories, such level of detail is usually absent (DePaulo et al. 2003). Fourth, we triangulated our data wherever possible by cross-referencing high profile incidents (e.g., large-scale "gang" raids) with news reports, examining official documentation when possible (e.g., warrants, court/TCHC documents, notices on doors), asking participants about these instances multiple times and cross-checking over the study period; witnessing remnants of recent police raids (e.g., damaged entryways, sofas), and interviewing/speaking with multiple individuals who were present (e.g., partners, family, friends) and cross-checking these accounts. Fifth, allegations of police misconduct were consistent across both neighborhoods, though many participants were unknown to or even had serious "beefs" with each other. Though we cannot scientifically conclude that any of our participants' accounts actually occurred, the consistency in their narratives should give us pause.

This study has focused specifically on the experiences of a particular subset of residents in two Toronto inner-city neighborhoods, both policed by the same division. Consequently, our participants' perceptions of police abuse and misconduct may not generalizable beyond this sample or local context. However, the inherently invasive nature and increasing militarization of police raids likely influences perceptions of police legitimacy in other contexts. The extent to which they do, and how this may be affected by various factors (i.e. perceptions of treatment, race/ethnicity, social and economic status, neighborhood, purpose and yield of the raid, etc.) is a question for future empirical work in this area. In particular, future research must account for where, why and how raids are deployed as this may enhance our knowledge of their impact on marginalized communities and police-community relations.

\section{References}

Aldana, R. (2007). Of Katz and aliens. University of California Davis Law Review, 41:1081.

Anderson, E. (1990). Streetwise. Chicago: University of Chicago Press.

Anderson, E. (1999). Code of the Street. New York: W.W. Norton.

Ayoyo, D.D. (2018). The Perceptions of Police-Black Civilian Deadly Encounters in North America among Black Immigrants in a Western Canadian City, Societies, 8(2):42. 
Baker, T., Pelfrey, W.V., Bedard, L.E., Dhungana, K., Gertz, M., Golden, K. (2014). Female Inmates' Procedural Justice Perceptions of the Police and Courts: Is There a Spill-Over of Police Effects? Criminal Justice and Behavior, 41(2):144-162.

Baker, T., Pickett, J.T., Amin, D.M, Golden, K., Dhungana, K., Gertz, M., Bedard, L. (2015). Shared race/ethnicity, court procedural justice, and self-regulating beliefs: A study of female offenders. Law and Society Review, 49:433-65.

Baker, T.W. (2017). Exploring the Relationship of Shared Race/Ethnicity With Court Actors, Perceptions of Court Procedural Justice, and Obligation to Obey Among Male Offenders. Race and Justice, 7(1):87102.

Barnes, S. (2011). Canada's densest neighbourhood, St. Jamestown, to possibly get new condos. Retrieved from Sep 22nd from https://www.wellesleyinstitute.com/housing/st-james-town-residents-feelpowerless-in-light-of-new-development-in-one-of-north-americas-densest-neighbourhoods/

Berardi, L. (2018). Shots Fired. Doctoral Dissertation. University of Alberta.

Brown, B. \& Benedict, W.R. (2002). Perceptions of the police. Policing: an international Journal of Police Strategies and Management, 25(3):543-580.

Brunson, R.K. (2007). “Police Don't Like Black People”: African-American Young Men's Accumulated Police Experiences. Criminology \& Public Policy, 6(1):71-102

Brunson, Rod, Miller., J. (2006). Young black men and urban policing in the United States. British Journal of Criminology, 46:613-640.

Brunson, R.K. \& Weitzer, R. (2009). Police relations with black and white youths in different urban neighborhoods. Urban Affairs Review, 44(6):858-885.

Cao, L. (2011). "Visible Minorities and Confidence in the Police." Canadian Journal of Criminology and Criminal Justice, 53(1):1-26.

Chan, W. \& Chunn, D. (2014). Racialization, crime, and criminal justice in Canada. Toronto: University of Toronto Press.

Charmaz, K. (2011). “Grounded Theory Methods in Social Justice Research. "In Denzin Norman and Yvonna Lincoln (Eds.), Handbook of Qualitative Research, 4(3):59-380.

Cohen, J., Gorr, W., Singh, P. (2003). Estimating intervention effects in varying risk settings. Criminology, 41(2):257-292. 
Cooper, H.L. (2015). War on drugs policing and police brutality. Substance Use and Misuse, 50(8):11881194.

Davis, S.S. \& Appleby, T. (2011). Residents of Toronto public housing four times more likely to be murder victims Retrieved Sep 22nd from https://www.theglobeandmail.com/news/toronto/residentsof-toronto-public-housing-four-times-more-likely-to-be-murder-victims/article586043/

DePaulo, B.M., Lindsay, J.J., Malone, B.E., Muhlenbruck, L., Charlton, K., Cooper, H. (2003). Cues to deception. Psychological Bulletin,129:74-118.

Edmiston, J. (2016). Toronto police officer accused of planting heroin faces obstruction, perjury charges in another case. https://nationalpost.com/news/toronto/toronto-police-officer-accused-of-plantingheroin-now-facing-obstruction-perjury-charges-in-another-case

Evans, K. (2009). The ICE storm in U.S. homes: An urgent call for policy change. NYU Review of Law and Social Change, 33:561-611.

Fisher, J. (2010). SWAT Madness and the Militarization of the American Police: A National Dilemma: A National Dilemma.

Fox, C.(2018). Four Toronto cops accused of planting drugs on suspect. CP24

https://www.cp24.com/news/four-toronto-cops-accused-of-planting-drugs-on-suspect-1.2755532

Freeze, C. (2014). At Toronto Community Housing, A History of Violence. February 15. The Globe and Mail.

Gau, J.M. \& Brunson, R.K.(2010). Procedural Justice and Order Maintenance Policing: A Study of InnerCity Young Men's Perceptions of Police Legitimacy. Justice Quarterly, 27(2):255-279.

Gau, J.M., Corsaro, N., Stewart, E.A., Brunson, R.K. (2012). Examining Macro-level Impacts on Procedural Justice and Police Legitimacy. Journal of Criminal Justice, 40(4):333-343.

Gau, J.M., Brunson, R.K. (2015). Procedural injustice, lost legitimacy, and self-help. Journal of Contemporary Criminal Justice, 31(2):132-150.

Gillis, W. (2020). Toronto cop charged with professional misconduct over pepper-spray incident judge called "obvious police brutality" https://www.thestar.com/news/gta/2019/03/13/toronto-cop-charged-withprofessional-misconduct-over-pepper-spray-incident-judge-called-obvious-police-brutality.html Goffman, A. (2015). On the run: American life in a fugitive city. Chicago: Chicago UP. Guest, G., Bunce, A., Johnson, L. (2006). “How Many Interviews are Enough?” Field methods, 18(1):59-82. 
Greene, C., Urbanik, M-M., Yankey, M-K. (2020). "I'm Wise To The Game”: How inner-city women experience and navigate police raids. Unpublished Manuscript.

Hinds, L. \& Murphy, T. (2007). Public Satisfaction With Police. Australian and New Zealand Journal of Criminology, 40(1):27-42.

Ivković, S.K. (2009). Rotten apples, rotten branches, and rotten orchards. Criminology and Public Policy, 8:777-785.

Jackson, P. (1994). Constructions of criminality. Antipode, 26(3):216-235.

Jackson, J., Bradford, B., Hough, M., Myhill, A., Quinton, P., Tyler, T.R. (2012): Why do people comply with the law? British Journal of Criminology, 52(6):1051-1071.

Jacobs, B. (2000). Robbing drug dealers. New York: Aldine de Gruyter.

Juby, C., Kaplan, L. (2011). Postville: The effects of an Immigration Raid. Families in Society, 92:147-153.

Karamali, K. (2020). "We're sick and tired of it": Members of Toronto neighbourhood share stories of antiBlack racism. Retrieved Sep 22nd from https://globalnews.ca/news/7029521/anti-black-racismjamestown-community-stories-toronto/

Katawazi, M. (2019). SIU charges Toronto police officer with assault. https://toronto.ctvnews.ca/siucharges-toronto-police-officer-with-assault-1.4622703?cache=\%3FclipId\%3D104069

Kraska, P.B. (2007). Militarization and policing. Policing, 1:501-513.

Kraska, P.B, \& Kappeler, E.V. (1997) Militarizing American police. Social Problems,44:1-18.

LaFree, G. (2018). Losing Legitimacy. Routledge: New York.

Lebron, C.J. (2017). The Making of Black Lives Matter: A Brief History of an Idea. New York: Oxford UP.

Lopez, W.D., Kruger, D.J., Delva, J., Llanes, M., Ledón, C., Waller, A., Israel, B. (2017). Health implications of an immigration raid. Journal of immigrant and minority health, 19(3):702-708.

Loriggio, P. (2020). James Forcillo, officer who fatally shot teen Sammy Yatim on Toronto streetcar, gets full parole. Retrieved June 9th https://nationalpost.com/news/full-parole-for-toronto-cop-who-shot-teensammy-yatim-on-empty-streetcar

Madon, N. S., Murphy, K., Sargeant, E. (2017). Promoting police legitimacy among disengaged minority groups. Criminology \& Criminal Justice,17(5):624-642. 
Marché, G.E. (2009). Integrity, culture, and scale: an empirical test of the big bad police agency. Crime, Law, Society and Change, 51:463-486.

Mazerolle, L., Bennett, S., Antrobus, E., Eggins, E.(2012). Procedural justice, routine encounters and citizen perceptions of police. Journal of experimental criminology,8(4):343-367.

Mccluskey, J. D., Mastrofski, S. D., Parks, R. B. (1999). To Acquiesce or Rebel: Predicting Citizen Compliance with Police Requests. Police Quarterly, 2(4):389-416.

McKeganey, N. \& McGallagly, J. (2013) Nicked: drug users' views of drug enforcement, Journal of Substance Use, 18(4):320-334.

Meng, Y. (2017). Profiling minorities: police stop and search practices in Toronto, Canada. Human Geographies, 11(1):5-23.

Murch, D. (2015). Historicizing Ferguson. New Politics, 15(3):5.

Murphy, K. (2013) Policing at the margins. Journal of Policing, Intelligence and Counter Terrorism, 8:184199.

Murphy, K., Madon., N.S., Cherney, A. (2017). Promoting Muslims' cooperation with police in counterterrorism. Policing: An International Journal, 40(3):544-559.

Paternoster, R., Brame, R., Bachman, R., Sherman, L. (1997). Do Fair Procedures Matter? The Effect of Procedural Justice on Spouse Assault. Law \& Society Review, 31(1):163-204.

Pazzanno, S. (2019). Suicidal cop was target of internal theft, perjury investigation. Retrieved June 9th https://torontosun.com/news/crime/exclusive-suicidal-cop-was-target-of-internal-theft-perjuryinvestigation

Nagin, D.S. \& Telep, C.W. (2017). Procedural justice and legal compliance. Annual Review of Law and Social Science, 13:5-28.

Phillips, C. \& Bowling, B. (2003). Racism, ethnicity and criminology. British Journal of Criminology, 43(2):269-290.

Phillips, S.W. \& Wheeler, A., Kim, D.Y. (2016). The effect of police paramilitary unit raids on crime at micro-places in Buffalo, New York. International Journal of Police Science $\mathcal{E}$ Management,18(3):206-219.

Polletta, F. (2006). It Was Like a Fever. University of Chicago Press. 
Powell, B. (2016). Deputy chief Peter Sloly slams bloated police budget. Retrieved from https://www.thestar.com/news/gta/2016/01/18/deputy-chief-peter-sloly-pushes-for-change-amidlow-point-and-looming-crisis.html

Presser, L. (2009). The narratives of offenders. Theoretical Criminology, 13(2):177-200.

Presser, L. (2016). Criminology and the narrative turn. Crime, Media, Culture, 12(2):137-151.

Punch, M. (2000). Police Corruption and its Prevention. European Journal on Criminal Policy and Research, 8:301-324.

Rickford, R. (2015). Black Lives Matter: Toward a modern practice of mass struggle. New Labor Forum, 25(1):34-42.

Roziere, B. \& Walby, K. (2018). The expansion and normalization of police militarization in Canada. Critical Criminology, 26(1):29-48.

Roziere, B., \& Walby, K. (2019). Police militarization in Canada. Policing: A Journal of Policy and Practice, 13(4):470-82.

Sandberg, S. (2010). What can "Lies" Tell Us about Life? Journal of Criminal Justice Education, 21(4):447465.

Sarre, R. \& Prenzler, T. (2018). Ten key developments in modern policing. Police Practice and Research, 19(1):3-16.

Sherman, L.W. (1993). Defiance, Deterrence, and Irrelevance: A Theory of the Criminal Sanction. Journal of Research in Crime and Delinquency, 30(4):445-73.

Sherman, L.W., Rogan, D.P., Edwards, T., Whipple, R., Shreve, D., Witcher, D. (1995). Deterrent effects of police raids on crack houses. Justice Quarterly, 12(4):755-81.

Skogan, W.G. (2006). Police and Community in Chicago. New York: Oxford University Press.

Skogan W.G. \& Meares, T.L. (2004). Lawful Policing. The Annals of the American Academy of Political and Social Science, 593(1):66-83.

Small, M.L.(2009). How Many Cases Do I Need?: On Science and the Logic of Case Selection in FieldBased Research. Ethnography,10(1):5-38.

Son, I.S. \& Rome, D.M. (2004). The Prevalence and Visibility of Police Misconduct: A Survey of Citizens and Police Officers. Police Quarterly, 7(2):179-204. 
Sprott, J.B. \& Doob, A.N. (2009). 'The Effect of Urban Neighborhood Disorder on Evaluations of the Police and Courts', Crime and Delinquency, 55(3):339-62.

Sprott, J.B. \& Doob A.N. (2014). 'Confidence in the Police. Canadian Journal of Criminology and Criminal Justice, 56(3):367-79.

Sprott, J. B., \& Greene, C. (2010). Trust and Confidence in the Courts: Does the Quality of Treatment Young Offenders Receive Affect Their Views of the Courts? Crime and Delinquency, 56(2):269-289.

Tonry, M. (2010). The social, psychological, and political causes of racial disparities in the American criminal justice system. Crime \& Justice,39:273-312.

Tyler, T.R. (2003), 'Procedural Justice, Legitimacy, and the Effective Rule of Law', In M. Tonry, ed., Crime and Justice: A Review of the Research,30:283-357. Chicago: University of Chicago Press.

Tyler, T.R. (2005). Policing in black and white. Police Quarterly,5(8):322-42.

Tyler, T. (2017). Procedural justice and policing: A rush to judgment? Annual Review of Law and Social Science,13:29-53.

Tyler, T.R. \& Fagan, J., Geller, A. (2014). Street stops and police legitimacy. Journal of empirical legal studies,11(4):751-85.

Tyler, T. R., Huo, Y.J. (2002). Trust in the Law. Russell Sage Foundation.

Tyler, T. R. \& Wakslak, C.J. (2004). Profiling and police legitimacy. Criminology, 42(2):253-82.

Urbanik, M-M. (2017). "More People Are Dying": An Ethnographic Analysis of the Effects of Neighbourhood Revitalization on the Lives of Criminally Involved Men. Doctoral Dissertation. University of Alberta.

Urbanik, M-M. (2018). Drawing Boundaries or Drawing Weapons? Neighborhood Master Status as Suppressor of Gang Violence. Qualitative Sociology, 41:497-519.

Urbanik, M-M., Thompson, S.K., Bucerius, S.M. (2017). 'Before There Was Danger But There Was Rules. And Safety in Those Rules': Effects of Neighbourhood Redevelopment on Criminal Structures. The British Journal of Criminology, 57(2): 422-440.

Urbanik, M-M., Greene, C., Wojnarowicz, J. (2020). “There's a Certain Group of Cops that Have Their Own Vendetta": Resident Perceptions of Notorious Police Officers and "Cop Clockin" in the Inner-City. Unpublished Manuscript. 
Venkatesh, S. (2002). "Doin' the Hustle": Constructing the Ethnographer in the American Ghetto. Ethnography, 3(1):91-111.

Wacquant, L. (2010). Urban desolation and symbolic denigration in the hyperghetto. Social Psychology Quarterly,73(3):215-19.

Walby, K. \& Roziere, B. (2018). Rise of the SWAT team: Routine police work in Canada is now militarized. Retrieved September 22nd from https://theconversation.com/rise-of-the-swat-teamroutine-police-work-in-canada-is-now-militarized-90073

Warren, S. \& Vincent, C. (2001). “This won't take long ...”: Interviewing, ethics and diversity, International. Journal of Qualitative Studies in Education, 14(1):39-53,

Weitzer, R. (2017) Theorizing racial discord over policing before and after Ferguson. Justice Quarterly, 34(7):1129-1153.

Wortley, S. \& Owusu-Bempah, A. (2009). Unequal before the law. International Migration and Integration, 10(4):447-473.

Wortley, S. \& Owusu-Bempah, A. (2011). The usual suspects. Policing and society, 21(4):395-407.

\section{Contributors}

Marta-Marika Urbanik is an Assistant Professor in the Department of Sociology, at the University of Alberta. An urban ethnographer, her research interests include gang processes and violence, inner-city policing, neighbourhood redevelopment, and the street code on social media.

Carolyn Greene is an Associate Professor of Criminal Justice at Athabasca University. Her research interests include policing marginalized communities, bail and remand, the operation of the youth criminal justice system in Canada, and perceptions/experiences of the criminal justice system.

\section{Footnotes}

1. C.f. Baker 2017; Baker et al. 2015; Brunson \& Miller 2006, Brunson \& Weitzer 2009, Gau et al 2012, Gau \& Brunson 2010; 2015.

2. While being stopped and searched may not be considered an 'every day' police interaction for dominant group members, these contacts may be commonplace for racialized individuals. $€$

3. Some scholars, exploring views across diverse participant groups, find procedural justice may be contingent on context, suggesting its effects differ across communities and population groups (Madon et al., 2017; Wolfe et al., 2016). 
4. In Canada, raids are typically referred to as "search warrant executions."

5. The development of paramilitary units was originally intended for hostage situations and terrorist attacks (Cooper 2015). $\doteq$

6. For a critical discussion of the militarization of Canadian police, see Roziere and Walby (2018).

7. This has increased police brutality despite questionable effectiveness in reducing street-level drug activity (Cooper 2015). $\doteq$

8. This number includes immigration and non-immigration raids. $\subseteq$

9. Goffman (2015) has discussed raids but has not systematically examined their impact. Canadian scholarship examining police raids has predominantly focused on SWAT and police militarization (Cyr et al. 2020; Roziere \& Walby 2018/2019). The majority of raid research has focused exclusively on immigration-related raids, many of which occur at workplaces (Aldana 2007; Evans 2009; Juby \& Kaplan 2011; Lopez et al. 2017). Such raids differ significantly from non-immigration raids, which usually involve police forcing their way into private homes, securing, conducting full searches of dwellings and apprehending those suspected of criminal activity (beyond immigration-related offenses) and/or securing evidence of criminal activity, for example, guns, drugs, and money. 10. At present, the limited data on the prevalence, location, purpose of police raids, and demographical information of raid suspects makes it impossible to determine if a) raids are disproportionately concentrated in lower-income areas, and b) if so, whether this concentration is justified by disproportionate drug trafficking and other offenses in such areas in comparison to neighborhoods of higher socioeconomic status. $\bullet$

11. Blake-Boultbee was excluded as only one respondent had experienced a raid, and a different division polices the neighborhood. $\bullet$

12. In Canada, such data is rarely publicly available.

13. In 2016 , compared to city averages of $27 \%$ and $22 \%$.

14. As compared to $51.5 \%$ for the city, $14 \%$ identify as Black as compared to the city average of $8.9 \%$ (Statistics Canada 2019). $\bullet$

15. Homes/apartments where illicit drugs are produced/sold. $\subseteq$

16. Residents used the term "raid" to describe both SWAT searches and police residential searches undertaken without SWAT attendance. $\doteq$ 
17. Under Canadian law, police are required to have and produce copies of Justice of the Peace granted search warrants when entering and searching private dwellings (See Canadian Criminal Code s.320.29 and 487). Section 8 of the Canadian Charter of Rights and Freedoms stipulates that all citizens are to be protected from unreasonable search and seizure. However, this may warrant requirement may be waived under exigent circumstances. $\triangleq$

18. Pseudonyms used throughout. Details and identifying information changed to protect participants' identities. $\doteq$

19. Canadian police officers are required to report all property seized (whether specified in a warrant or unspecified) to a Justice of Peace (S.489, Canadian Criminal Code). $\leftrightarrows$

20. Irrespective of whether they charged with a crime or not, had charges dropped, found not guilty, or if a Judge found the items to have been unreasonably seized. $\boxminus$

21. Participants' accounts did not include accusations of evidence planting or overstating the quantity/value of goods seized. $ヒ$

22. See Skogan \& Meares (2004) for a discussion of police corruption motivated by personal and organizational gains. $\bullet$

23. Ricky was involved in large-scale drug trafficking at the time. $ヒ$

24. See Greene et al. (2020) for more context and a gendered analysis of police raids.

25. Several of our participants reported police 'stole' personal identification during raids and street interactions. $\bullet$

26. See also Rios (2017:69).

27. See also Weitzer \& Brunson (2009:246-248).

28. This skepticism may be influenced by social standing and behaviors, as the narratives of lowerstatus groups are less likely to be believed (Polletta 2006, p. 176). Whilst some believe offenders lie more than those not criminally involved, scholars have argued this belief has no legitimate basis (Jacobs 2000). $匚$ 